\title{
カーボンナノチューブへの $\mathrm{SiC}$ 被覆とその応用
}

\author{
SiC Coating on Carbon Nanotubes and Its Applications
}

\begin{abstract}
03125
研究代表者 大阪大学接合科学研究所 教授 宮 本 欽 生 Yoshinari Miyamoto

共同研究者 大阪大学接合科学研究所
\end{abstract}

大学院博士後期課程 森 貞 好 昭 Yoshiaki Morisada

\begin{abstract}
A new $\mathrm{SiC}$ coating method on multi-walled carbon nanotubes has been developed by using the reaction between $\mathrm{SiO}$ vapor and carbon at $1250^{\circ} \mathrm{C} \sim 1450^{\circ} \mathrm{C}$ in vacuum. The growth mechanism of $\mathrm{SiC}$ layer was clarified. The $\mathrm{SiC}$ coating improved significantly the oxidation resistance of carbon nanotubes. SiC-coated carbon nanotubes were applied as reinforcements to wear resistant materials. Dense SiC-coated carbon nanotubes reinforced $\mathrm{SiC}$ composites were successfully fabricated by spark plasma sintering. These composites showed superior mechanical properties.
\end{abstract}

\section{研究目的}

カーボン原子間の化学結合には $\mathrm{sp}, \mathrm{sp}^{2}$, そして $\mathrm{sp}^{3}$ の 3 種の混成軌道が存在し，これが他に類を見ないカ ーボン材料の多種多様性を創出している ${ }^{1)} 。$ 近年では フラーレン, カーボンナノチューブといったニューカ 一ボン材料が発見され ${ }^{2), 3)}$, カーボンは材料研究にお ける世界的ブームの中心に位置しているといっても過 言ではない。

しかしながら, 全てのカーボン材料は酸化反応とい う極めて本質的な問題点を共有している。特に微細な カーボンナノチューブに均一な被覆を施すことは極め て困難である。これら微細カーボン材料への $\mathrm{SiC}$ 被覆 が可能になれば，その効果は耐酸化特性の改善に留ま らない。多層カーボンナノチューブは極めて高い強度 を有することから各種マトリックスの強化材として期 待されているが，その滑らかな表面形状からマトリッ クスとの密着性にそしく，思うような成果が得られて いない" ${ }^{4)}$ 。 $\mathrm{SiC}$ 被膜は溶融金属からカーボンナノチュ ーブを保護し, 表面形状を制御することも可能であり,
このような問題点を克服する可能性を秘めている。本 研究は SiO ガスを用いて多層カーボンナノチューブ を蒸焼きにする簡便な $\mathrm{SiC}$ 被覆法を新たに開発し, カ ーボンナノチューブのより広い応用を目指している。

\section{研究内容および成果}

\section{1.ナノ $\mathrm{SiC}$ 被覆法}

カーボン材料への $\mathrm{SiC}$ 被覆法としては各種 CVD 法, 転換法, シラン系ポリマーの熱分解を利用した方法等 が存在するが，それぞれ欠点を有している。CVD 法 は制御すべき因子が多い上，危険を伴う。転換法はカ ーボン材料を $\mathrm{SiC}$ に転換する手法である為, カーボン ナノチューブ等の微細カーボン材料には不向きであ る。ポリマーを用いた手法も微細カーボン材料への均 一被覆には適しておらず, コスト面からも実用的では ない。本法は転換法と CVD 法の特徴を取入れた簡便 な新規 $\mathrm{SiC}$ 被覆手法である。Fig. 1 に示すように, ア ルミナ坩堝の下部に $\mathrm{SiO}$ 顆粒を配置し, その上にカ 


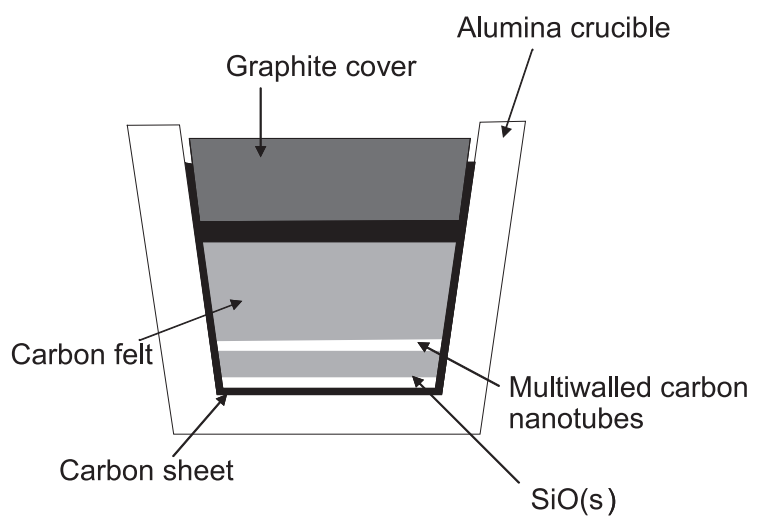

Fig.1 Assembly for the $\mathrm{SiC}$ coating of diamond particles.

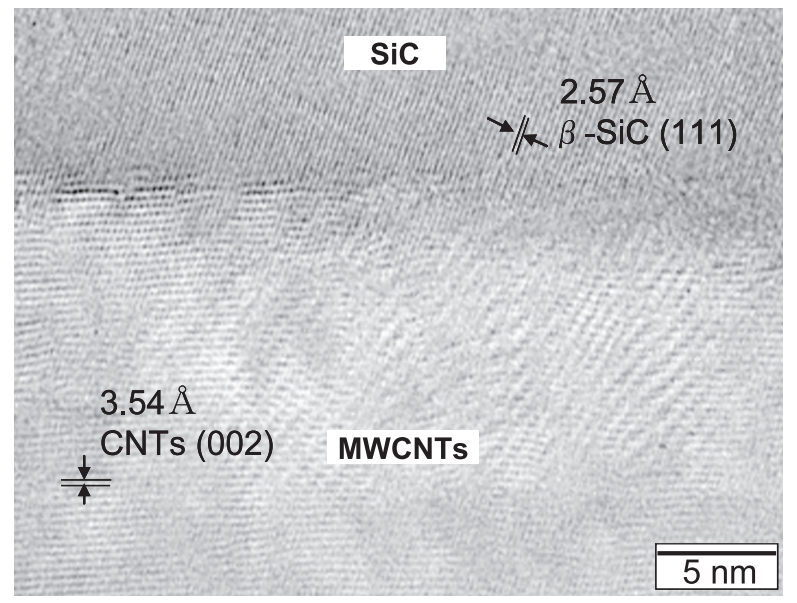

Fig.2 TEM photograph of the SiC-coated MWCNTs treated at $1350{ }^{\circ} \mathrm{C}$ for $15 \mathrm{~min}$ with carbon source.

ーボンフェルトを介して多層カーボンナノチューブを 挿入する。これを目的の被覆温度で熱処理するだけで $\mathrm{SiC}$ 被覆が達成される。坩堝上部はカーボンフェルト， カーボンシートで密閉され, $\mathrm{SiO}$ ガスを初めとする各 種生成ガスを一定時間坩堝内に滞留させる設計になっ
ている。Fig. 2 の HR-TEM 写真に示すように，カー ボンナノチューブの (002) 面と $\beta-\mathrm{SiC}$ の (111) 面が 明瞭に観察され， $\mathrm{SiC}$ 被覆が達成されていることが確 認できる。

\section{2.ナノ $\mathrm{SiC}$ 被膜生成機構}

Fig. 3 に $1350^{\circ} \mathrm{C}$ で 15 分間の被覆処理を施した $\mathrm{SiC}$ 被覆カーボンナノチューブの SEM 写真を示す。(a) は前述の坩堝内配置で被覆処理を行ったもの，（b）は カーボンフェルト, カーボンシートを使用せず，坩堝 内に $\mathrm{SiO}$ 顆粒と多層カーボンナノチューブのみを配 置して被覆処理を行ったものである。 $\mathrm{SiC}$ 被覆カーボ ンナノチューブの表面形状が明らかに異なっており, （b）のサンプル表面は（a）のものと比較して滑らかで ある。この表面形状の差異は $\mathrm{SiC}$ 被膜の生成機構が異 なることを示している。また, Fig. 4 に示す XRD パ ターンに拈いても明瞭な違いが見られる。（b）のサン プルでは被覆温度の上昇に伴い, カーボンナノチュー ブに起因するピークの強度が低下しており，1450 Cを

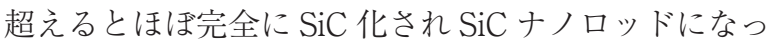
ている。これに対し，(a)のサンプルについては被覆 温度の上昇に伴い, $\beta-\mathrm{SiC}$ のピーク強度が増加して いるにもかかわらず, カーボンナノチューブのピーク 強度に大きな変化はない。つまり，(a)においては $\mathrm{SiC}$ 被膜がカーボンナノチューブの内部方向に生成す るのではなく，カーボンナノチューブ上に生成してい るものと考えられる。

以上の結果から，次のような $\mathrm{SiC}$ 被膜生成機構が考 えられる。 $\mathrm{SiC}$ 被膜生成の初期において, $\mathrm{SiO}$ ガスと 多層カーボンナノチューブの表面が反応することで薄 い $\mathrm{SiC}$ 層が形成される。
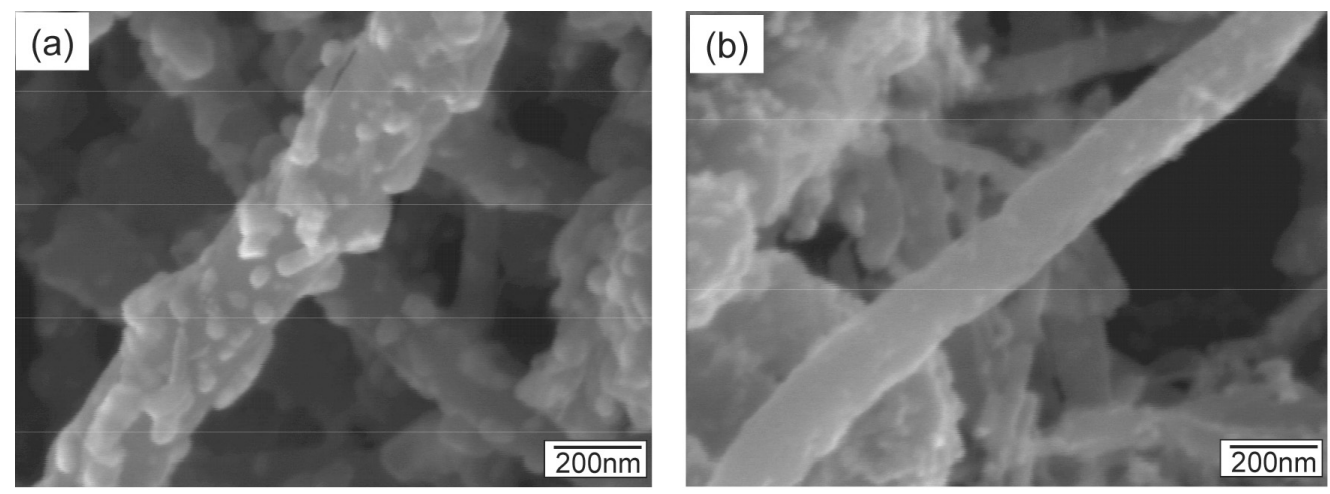

Fig.3 SEM photographs of the SiC-coated MWCNTs treated with carbon source (a) and without carbon source (b) at $1350^{\circ} \mathrm{C}$ for $15 \mathrm{~min}$. 


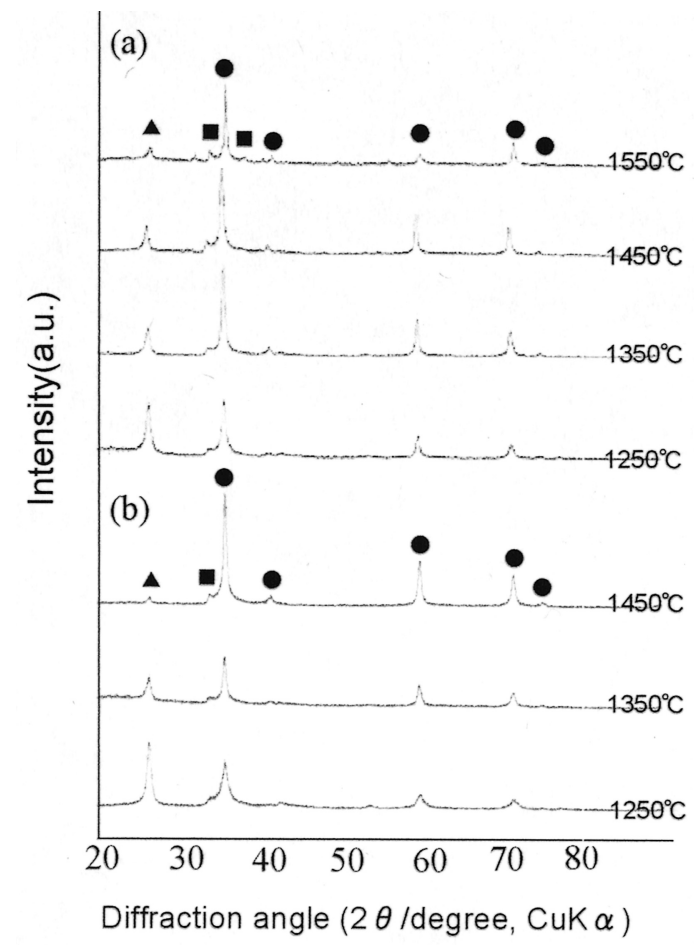

Fig.4 XRD patterns of the SiC-coated MWCNTs treated with carbon source (a) and without carbon source (b) at various temperatures for 30 min. $\boldsymbol{\Delta}:$ MWCNTs $\bigcirc ~: \beta-\mathrm{SiC} \mathbf{\square}: \alpha-\mathrm{SiC}$

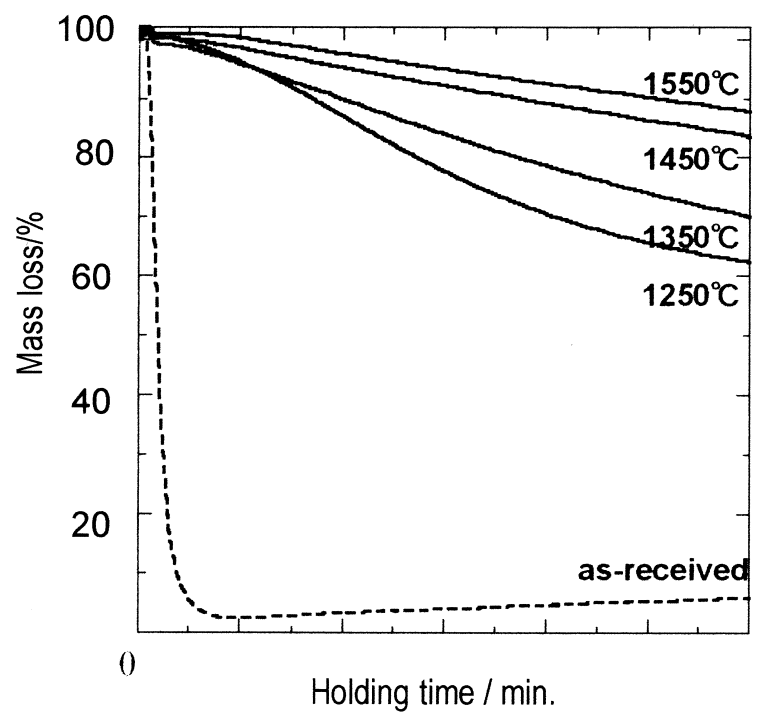

Fig.5 TG curves for the SiC-coated MWCNTs heated at $650{ }^{\circ} \mathrm{C}$ in air. The coating was conducted at various temperatures from $1250^{\circ} \mathrm{C}$ to $1550^{\circ} \mathrm{C}$.

$\mathrm{SiO}(\mathrm{g})+\mathrm{CNTs}=\mathrm{SiC}(\mathrm{s})+\mathrm{CO}(\mathrm{g})$

これは一般的な転換法による $\mathrm{SiC}$ 生成と同様の反応 である。坩堝内にカーボンフェルト，カーボンシート
等の十分な炭素源が存在しない場合，この反応が継続 的に進行することになる。これに対し，本被覆法にお いては以下の反応で主に $\mathrm{SiC}$ が生成しているものと思 われる。

$$
\mathrm{SiO}(\mathrm{g})+3 \mathrm{CO}(\mathrm{g})=\mathrm{SiC}(\mathrm{s})+2 \mathrm{CO}_{2}(\mathrm{~g})
$$

CO ガスは反応 (1) に加え, カーボンシート等と $\mathrm{SiO}$ ガスとの反応によっても生成される。また, 反応 (2)によって生成される $\mathrm{CO}_{2}$ ガスは坩堝内に存在する 過剩の炭素源と反応することで, 更にCO ガスを供給 すると共に反応 (2) の進行を促進する（反応 (3))。 カーボンナノチューブ自身も炭素源として働く為, (b) のサンプルにおいても若干の $\mathrm{SiC}$ 粒の析出は起こ るが, 基本的には反応（1）によって $\mathrm{SiC}$ 被膜が形成さ れる。

$$
\mathrm{CO}_{2}(\mathrm{~g})+\mathrm{C}(\mathrm{s})=2 \mathrm{CO}(\mathrm{g})
$$

このように，本法は転換法と CVD 法が融合した被 覆手法であり, 非常に簡便な上, 極めて微細なカーボ ン材料に対して効果的な被覆法である。初期の反応で 形成される薄い $\mathrm{SiC}$ 被膜も重要な役割を有しており, $\mathrm{SiC}$ 粒子が析出する良好な下地となるのみでなく, $\mathrm{SiC}$ とカーボン材料の組成的な差異を傾斜組織によっ て緩和することで $\mathrm{SiC}$ 被膜の密着性を向上させる。

\section{3. ナノSiC被覆カーボンナノチューブの耐酸 化特性}

Fig. 5 に空気中， $650^{\circ} \mathrm{C}$ に打けるカーボンナノチュ ーブ及び $\mathrm{SiC}$ 被覆カーボンナノチューブの質量変化を 示す。 $\mathrm{SiC}$ 被覆による酸化耐久性の向上は明らかであ る。カーボンナノチューブが約 5 分間で完全に酸化さ れているのに対し, $1550^{\circ} \mathrm{C}$ で被覆処理をしたカーボン ナノチューブは 60 分保持後も約 $90 \%$ の質量が残存し ている。より高い温度での被覆処理がより大きな酸化 耐久性の向上を示しているが, これは被膜の緻密化に よるものであると考えられる。 $\mathrm{SiC}$ 被覆の効果は SEM 観察に扔いても明膫に現れている。カーボンナ ノチューブ先端のキャップは容易に酸化されることが 知られて抢り ${ }^{5}$, 10 秒間の酸化で完全に消失していた。 また，側面においても酸化反応の進行がうかがえる。 一方， $\mathrm{SiC}$ 被覆を施した場合は 60 分後もキャップが 

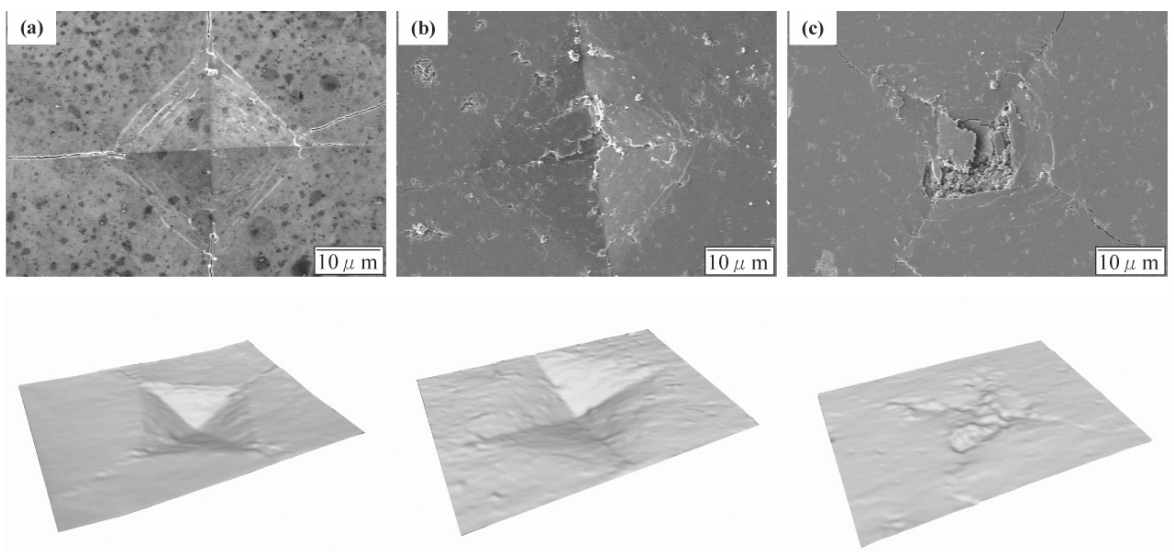

Fig.6 SEM and 3D images of the indentation: (a) monolithic SiC, (b) MWCNTs/SiC composite, (c) SiC-coated MWCNTs/SiC composite.

Table 1 Effect of test load on the microhardness and fracture toughness.

\begin{tabular}{lcccc}
\hline \multicolumn{1}{c}{ Materials } & \multicolumn{2}{c}{$\begin{array}{c}\text { Microhardness } \\
(\mathrm{GPa})\end{array}$} & $\begin{array}{c}\text { Fracture toughness } \\
\left(\mathrm{MPa} \cdot \mathrm{m}^{1 / 2}\right)\end{array}$ \\
\hline & $<9.8 \mathrm{~N}>$ & $<19.6 \mathrm{~N}>$ & $<9.8 \mathrm{~N}>$ & $<19.6 \mathrm{~N}>$ \\
Monolithic SiC vol\% & 26.1 & 25.5 & 4.0 & 4.8 \\
MWCNTs (5 vol\%)/SiC & 20.5 & 25.8 & 4.4 & 4.6 \\
SiC coated MWCNTs (5 vol\%)/SiC & 34.3 & 30.6 & 7.1 & 5.4 \\
\hline
\end{tabular}

残存しており，処理前後でその形状に大きな変化は見 られていない。

\section{4.ナノSiC被覆カーボンナノチューブ/SiC} 複合材料

カーボンナノチューブをセラミックス基複合材料の 強化材として用いる試みは多数なされているが，期待 されているほどの効果が得られていないのが実状であ る。その原因の一つであるカーボンナノチューブ/マ トリックス間の密着性の低さを $\mathrm{SiC}$ 被覆によって改善 することが可能である。特にマトリックスを $\mathrm{SiC} と し$ た場合に顕著な効果が現れる。Fig. 6 にSPSにより $1800^{\circ} \mathrm{C}$ で高密度焼結した $\mathrm{SiC}$ 単体, カーボンナノチ ユーブ/ $\mathrm{SiC}$ 複合材料， $\mathrm{SiC}$ 被覆カーボンナノチュー ブ/ $\mathrm{SiC}$ 複合材料におけるビッカース圧痕の SEM 及

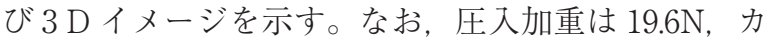
ーボンナノチューブ, $\mathrm{SiC}$ 被覆カーボンナノチューブ の添加量はそれぞれ 3vol\% である。 $\mathrm{SiC}$ 単体のビッカ 一ス圧痕は非常にシャープで，ダイヤモンド圧子の形 状をそのまま反映している。これに対し， $\mathrm{SiC}$ 被覆力 ーボンナノチューブ/ $\mathrm{SiC}$ 複合材料のビッカース圧痕 は不明瞭であり, 加重除去後の弾性回復が推測される。

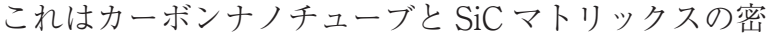
着性向上がもたらした結果である。未被覆のカーボン ナノチューブを分散させた場合には大きな効果は見ら れない。圧入加重 $9.8 \mathrm{~N}$ で測定したビッカース硬度及 び破壊鞁性值を Table 1 に示す。ビッカース硬度及 び破壊靯性值への $\mathrm{SiC}$ 被覆カーボンナノチューブ添加 の効果は明らかであり，わずか $5 \mathrm{vol} \%$ の添加量でそ れぞれ $34.3 \mathrm{GPa}, 7.1 \mathrm{MPa} \cdot \mathrm{m}^{1 / 2}$ に達している。

\section{今後の研究の見通し}

非常に簡便な手法を用いてカーボンナノチューブに 代表される微細なカーボン材料に均一な $\mathrm{SiC}$ 被覆を施 すことが可能であることを示した。 $\mathrm{SiC}$ 被覆は各種マ トリックスの強化材としてのカーボンナノチューブの 有効性のみならず，カーボンナノチューブ単体での利 用分野も拡大し得る。また, $\mathrm{SiC}$ 被膜表面を酸化して シリカ被膜にしてやることも可能である。カーボンナ ノチューブはダイヤモンドを凌ぐ熱伝導率を有してい るとも言われており，極めて高い熱伝導率と電気絶縁 性を共有する材料の創製も興味深い。 
参考文献

1 ）稲垣道夫, 菱山幸宥, ニューカーボン材料 (1994).

2 ) H.W. Kroto, J.R. Heath, S.C. O’Brien, R.F. Curl and R.E. Smalley, Nature, 318, 162 (1985).

3 ) S. Iijima, Nature, 352, 56 (1991).

4 ) E.T. Thostensona, Z. Renb, T.W. Choua, Composites Science and Technology, 61, 1899-1912 (2001).

5 ) Y. Saito, R. Mizushima, and K. Hata, Surface Science, 499, 119-123 (2002).
本助成金による主な発表論文

$1)$ Y.Morisada, M. Maeda, T.Shibayanagi and Y.Miyamoto, "SiC coating on MWCNTs", J.Ceram. Soc. Jpn., Suppl. 112-1, PacRim5 Special Issue, 112, S51-S53(2004).

2) Y.Morisada, M. Maeda, T.Shibayanagi and Y.Miyamoto, "SiC Coating on Multi-walled Carbon nanotubes and Its Oxidation Resistance”, J.Am. Ceram.Soc., 87, 804-08 (2004).

3 ) Y.Morisada and Y.Miyamoto, "SiC-coated Carbon Nanotubes and Their Application as Reinforcements for Cemented Carbides”, Mat. Sci. \& Eng. A, 381, 58-62 (2004).

4 ) Y.Morisada, Y.Takaura, K.Hirota, O.Yamaguchi and Y.Miyamoto, "Mechanical Properties of SiC Composites Incorporated SiC-coated Multi-walled Carbon Nanotubes", J.Am.Ceram.Soc., to have been submitted. 